\title{
ELECTROLYTE STUDIES ON PATIENTS WITH CIRRHOSIS OF THE LIVER
}

\author{
By WILLIAM J. EISENMENGER, SOLOMON H. BLONDHEIM,1 ALFRED M. \\ BONGIOVANNI, AND HENRY G. KUNKEL
}

(From The Hospital of The Rockefeller Institute for Medical Research, New York City)

(Submitted for publication May 1, 1950; accepted, August 16, 1950)

The relationship between the formation of ascites and dietary sodium in patients with cirrhosis of the liver is well established (1-4). Rigid restriction of ingested sodium provides a therapeutic procedure which is effective in arresting the accumulation of ascites in most cases of hepatic cirrhosis. However, the many factors conditioning the response to variations in ingested sodium are incompletely understood. Detailed studies of sodium and water metabolism, therefore, were carried out in a large group of patients with cirrhosis. Marked abnormalities were found which were characterized by extreme renal retention of sodium, as previously emphasized by Farnsworth and Krakusin (3), and by low values of serum sodium. Associated with minimal renal excretion of sodium, a more generalized phenomenon of conservation of sodium, as demonstrated in studies on saliva and sweat, suggests an hormonal relationship. It is not inferred that these abnormalities are primary. Rather it is felt that owing to the formation of excessive ascites they may reflect body mechanisms which are essentially protective in nature.

\section{MATERIALS AND METHODS}

All of the patients studied were admitted to The Hospital of The Rockefeller Institute for Medical Research. The history and clinical and laboratory findings were characteristic of Laennec's cirrhosis in the patients with large amounts of ascites, while among those with moderate or no ascites were included several patients with biliary cirrhosis or postnecrotic cirrhosis.

Diets were calculated and prepared by trained dietitians. For balance studies, each three-day lot of food, identical with that actually eaten by the patient, was analyzed for nitrogen, sodium, and potassium. Corresponding collections of stool and urine were likewise analyzed. Diets restricted in sodium were supplemented with whole protein foods of low sodium content. ${ }^{2}$ Sodium and potas-

\footnotetext{
1 U. S. Public Health Service Research Fellow of the National Institutes of Health.

2 Wyeth's "Low Sodium Food"; National Drug's "Protinal"; Squibb's "Melactin."
}

sium were determined by means of the Perkin-Elmer flame photometer; lithium was used as an internal standard.

Food and feces were prepared for analyses of sodium and potassium by ashing. The total three-day collection of feces or of food, including dietary fluids but not water, was pooled and mixed in a Waring blendor. To an aliquot of $10 \mathrm{gms}$. was added $1 \mathrm{cc}$. of $10 \% \mathrm{H}_{2} \mathrm{SO}_{4}$ to facilitate ashing. The aliquot was dried at approximately $90^{\circ} \mathrm{C}$. for two days and ashed at $300^{\circ} \mathrm{C}$. for one hour and then at $500^{\circ} \mathrm{C}$. for five hours. A small amount of black material in addition to the sodium and potassium caused no interference in the determination of the latter substances. The black material could be removed by heating at $800^{\circ} \mathrm{C}$., but at such temperatures a progressive loss of sodium and potassium occurred. The residue, redissolved in approximately $10 \mathrm{cc}$. of warm $0.1 \mathrm{~N}$ $\mathrm{H}_{2} \mathrm{SO}_{4}$, was filtered into a $100 \mathrm{cc}$. volumetric flask. The crucible and filter paper were washed five times with warm $0.1 \mathrm{~N} \mathrm{H}_{2} \mathrm{SO}_{4}$ and the volume was adjusted to 100 cc. with $0.1 \mathrm{~N} \mathrm{H}_{2} \mathrm{SO}_{4}$ after the solution of lithium required as an internal standard had been added. All determinations were performed in duplicate, the differences averaging less than $1 \%$. Several recovery determinations of sodium and potassium were done with each group of analyses, and were found to range from $96 \%$ to $104 \%$.

Serum sodium and potassium were also measured by means of the flame photometer, at a dilution of $1: 200$ for sodium and 1:10 for potassium; lithium was used as internal standard. To insure accuracy in the preparation of dilutions of serum, especially in the higher dilutions used in analyses of sodium, the same calibrated pipettes were used throughout, a $0.5 \mathrm{cc}$. blow pipette for sodium and a $1 \mathrm{cc}$. delivery pipette for potassium. Since the sera analyzed contained extremely variable concentrations of total protein ( 3 to $12 \mathrm{gms} . \%)$ and of lipids ( 0.4 to 3.8 gms.\%), the actual delivery of such sera by these pipettes was checked gravimetrically and was found to be satisfactory.

Owing to the high ratio of urinary potassium to sodium (in extreme sodium retention this may be $300: 1$ ), the interference by potassium in determinations of sodium was investigated and found to be small for practical purposes. With 300 parts of potassium to one part of sodium, when an internal standard was used, with one phototube a depression of $3 \%$ in sodium values was found but with another phototube there was no interference. Even in the most concentrated urines $(250 \pm$ cc. per day) with very low concentrations of sodium (ap- 
proximately 0.3 meq. per liter), recovery values accurately reflected the amount of sodium added.

Thermal sweat collected by the following method was analyzed for sodium. Sweating was stimulated by means of electric light heat cradles placed over the supine subject up to the mid thorax. In order to retain heat, the cradles were covered with blankets. Sweat was collected from an area in the epigastric region which was prepared by washing with distilled water and electrolytefree towels. In order to prevent evaporation, the prepared site was covered with a petri dish (approximately $8 \mathrm{~cm}$. in diameter) so placed that the entire edge was in direct contact with the skin. When sweating was profuse, droplets from the skin beneath the petri dish were collected by means of a Wintrobe pipette, $0.2 \mathrm{cc}$. being suffcient for analyses of sodium and potassium.

Saliva was analyzed for sodium and potassium. Approximately $10 \mathrm{cc}$. of saliva were collected in a test tube immediately on awakening in the morning and before any food or fluids were taken. This was collected without any stimulation. Only by such standardization were constant results obtained.

Plasma volume was determined by means of the dye T1824 (5). This procedure was also used for the determination of the volume of ascitic fluid. Approximately $0.5 \mathrm{cc}$. of T1824 was injected intraperitoneally for each estimated liter of ascites. After 15 minutes of manual massage of the abdomen following the injection, a sample of ascitic fluid was withdrawn. By this means, in the absence of significant edema, basal body weight was determined.

Chlorides in serum, ascites and urine were determined by the iodometric titration method of Van Slyke and Hiller (6). Chlorides in food and feces were measured by the open Carius method in samples of the original aqueous suspension. Concentrations of serum albumin were measured by the $\mathrm{Na}_{2} \mathrm{SO}_{4}$ method modified in this laboratory to obtain an accuracy of $\pm 3 \%$.

\section{RESULTS}

\section{Serum and urinary sodium in patients with} hepatic cirrhosis on a liberal intake of sodium

The content of sodium in 24-hour urines and the concentration of sodium in the postabsorptive sera of three groups of patients with chronic liver disease are presented in Table $I$. The patients are classified according to their tendency to form ascites. The 18 patients with "maximum ascites" accumulated ascitic fluid rapidly and required paracenteses at intervals of one to three weeks. "Moderate ascites" denotes those patients who accumulated fluid slowly or those who carried a limited amount of fluid for long periods of time without requiring paracenteses. The third group at no time had detectable ascites. These data were assembled during stabilized periods of liberal but fixed intake of sodium.

Minimal quantities of urinary sodium were characteristic of the group with maximal ascites. The renal excretion of sodium remained low in some of these patients despite variations in the daily dietary sodium from 10 to 170 meq. Excretion of sodium was generally higher in the second group. The third group of patients, having no ascites, eliminated in the urine all ingested sodium minus that lost in the feces and through the skin.

The concentrations of serum sodium were diminished in most patients in the first group to levels well below the normal fasting range (137 to 146 meq.). The levels of serum sodium in the latter

TABLE I

Urinary Sodium Excretion and Serum Sodium Levels in 3 Groups of Patients with

Chronic Liver Disease on a Sodium Intake of 120-150 meq./day.

\begin{tabular}{|c|c|c|c|c|c|c|c|c|}
\hline \multicolumn{3}{|c|}{ Maximum Ascites. } & \multicolumn{3}{|c|}{ Moderate Ascites } & \multicolumn{3}{|c|}{ No Ascites } \\
\hline Pt. & $\begin{array}{c}\text { Serum Na } \\
\text { meq./1. }\end{array}$ & $\begin{array}{l}\text { Urine Na } \\
\text { meq./day }\end{array}$ & Pt." & $\begin{array}{c}\text { Serum Na } \\
\text { meq. } / 1\end{array}$ & $\begin{array}{l}\text { Urine } \mathrm{Na} \\
\text { meq./day }\end{array}$ & Pt. & $\begin{array}{c}\text { Serum Na } \\
\text { meq./1. }\end{array}$ & $\begin{array}{l}\text { Urine Na } \\
\text { meq./day }\end{array}$ \\
\hline $\begin{array}{r}1 \\
2 \\
3 \\
4 \\
5 \\
6 \\
7 \\
8 \\
9 \\
10 \\
11 \\
12 \\
13 \\
14 \\
15 \\
16 \\
17 \\
18\end{array}$ & $\begin{array}{l}128 \\
130 \\
121 \\
140 \\
133 \\
137 \\
125 \\
129 \\
134 \\
130 \\
122 \\
131 \\
137 \\
125 \\
135 \\
120 \\
136 \\
141\end{array}$ & $\begin{array}{l}0.30 \\
0.25 \\
0.22 \\
1.50 \\
1.00 \\
0.60 \\
0.25 \\
3.00 \\
0.40 \\
0.25 \\
0.80 \\
0.12 \\
4.00 \\
0.23 \\
0.30\end{array}$ & $\begin{array}{l}19 \\
20 \\
21 \\
22 \\
23 \\
24 \\
25 \\
26 \\
27 \\
28\end{array}$ & $\begin{array}{l}136 \\
138 \\
139 \\
139 \\
133 \\
133 \\
140 \\
132 \\
137 \\
140\end{array}$ & $\begin{array}{r}18 \\
36 \\
60 \\
100 \\
125 \\
75 \\
\\
130 \\
24\end{array}$ & $\begin{array}{l}29 \\
30 \\
31 \\
32 \\
33 \\
34 \\
35 \\
36 \\
37 \\
38 \\
39 \\
40 \\
41\end{array}$ & $\begin{array}{l}136 \\
135 \\
138 \\
137 \\
136 \\
138 \\
139 \\
137 \\
137 \\
141 \\
135 \\
143 \\
136\end{array}$ & $\begin{array}{l}120 \\
115 \\
126\end{array}$ \\
\hline
\end{tabular}


TABLE II

Theoretical and determined ascites accumulation on different levels of sodium intake

\begin{tabular}{|c|c|c|c|c|c|}
\hline \multirow[b]{2}{*}{ Period } & \multirow[b]{2}{*}{$\begin{array}{l}\text { Na intake } \\
\text { meq./day }\end{array}$} & \multirow[b]{2}{*}{$\begin{array}{l}\text { Cl intake } \\
\text { meq./day }\end{array}$} & \multicolumn{3}{|c|}{ Average ascites accumulation in liters per day } \\
\hline & & & $\begin{array}{l}\text { Estimated from } \\
\text { weight gain } \\
\text { above basal weight }\end{array}$ & $\begin{array}{l}\text { Measured by } T_{1824} \\
\text { ascites volume } \\
\text { determinations }\end{array}$ & $\begin{array}{c}\text { Ascites } \\
\text { equivalent } \\
\text { of ingested } \mathrm{Na}\end{array}$ \\
\hline 14 days & 154 & 150 & +1.15 & +1.14 & +1.16 \\
\hline 14 days & 85 & 78. & +0.61 & +0.65 & +0.58 \\
\hline 35 days & 15 & 11 & -0.04 & -0.03 & $\mathbf{0}$ \\
\hline 8 days & 93 & 10 & +0.7 & - & +0.65 \\
\hline
\end{tabular}

two groups were within the lower normal range with few exceptions. Thus, cirrhosis with maximal ascites is usually associated with a low serum sodium in the face of marked renal retention of sodium on a liberal intake of salt.

\section{Relation of dietary sodium to the formation of ascites}

Fecal excretion of sodium was generally below 5 meq. per day. The sodium lost in insensible perspiration, as calculated by the difference between the amount ingested and the output in stool plus urine, was in agreement with the reported range of 4 to 10 meq. daily (7). Approximately 15 meq. of sodium were lost daily through the skin and stools.

In a patient with cirrhosis and ascites (Table II), who had a urinary output of sodium below 1

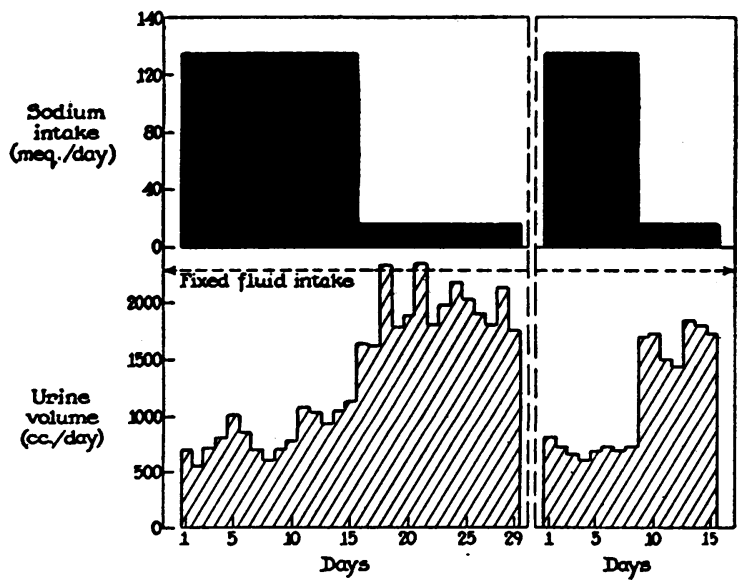

Fig. 1. IMMediate INCREase IN URINARY Volume after Restriction of Sodium in a Patient with Cirrhosis and Ascites and Minimal Urinary Excretion of SoDIUM meq. per day, the volume of abdominal fluid remained constant while the intake of sodium was limited to 15 meq. per day. When the ingestion of sodium exceeded 15 meq. per day, the volume of ascitic fluid, as measured by $\mathrm{T} 1824$ and by the gain in weight, increased to the extent predicted from the amount of excess sodium. This predicted gain in ascites was calculated on the basis of 120 meq. of sodium per liter of ascitic fluid, which concentration persisted in this patient throughout the period of observation. Following an increased intake of sodium but with restriction of chloride continued, retention of fluid resulted, corresponding to that anticipated from the augmented sodium alone. With this limitation of chloride there was a gradual fall of serum chloride to 80 meq. per liter with a comparable rise in plasma $\mathrm{CO}_{2}$.

As a corollary to the parallelism between dietary sodium and accumulation of ascites, an inverse relationship between ingested sodium and urinary volume was demonstrated (Figure 1). During two periods of restricted sodium, while intake of fluids was kept constant, the daily urinary volume increased approximately 1 liter. This was equivalent to the decrease in the previous daily accumulation of ascites. Similar responses to restriction of sodium are illustrated in Figures 2 and 3.

3. Metabolic effects of prolonged restriction of sodium (15 to 17 meq. per day) in patients with cirrhosis of the liver

A patient, whose record is depicted in Figure 2, was given daily 17 meq. of sodium after a control period of 154 meq. per day. The immediate arrest of the accumulation of ascites after restricting sodium is evident. The previously formed ascitic 
fluid persisted, and after five months began to disappear. The basal weight showed a gradual increase of $7 \mathrm{~kg}$. in six months.

The loss of sodium in insensible perspiration accounts for most of the apparent positive sodium balance in the initial months of observation. Most significant was the increasing amount of urinary sodium which resulted in a negative sodium balance. This indicated improvement long before it was clearly detectable by changes in body weight, urinary volume, or the amount of ascites.

Potassium balance, as influenced by restriction of sodium, was studied because of the intimate relationship of sodium and potassium to the regulation of intra- and extracellular fluids. Restriction of dietary sodium was promptly followed by an increased retention of potassium, resulting in a positive balance. However, nitrogen balance also became positive. The balances of potassium and nitrogen remained positive for a prolonged period, and the proportion of retained potassium to nitrogen approximated that in normal tissue protein, indicating protein anabolism. This is supported by the corresponding increase in basal body weight during the period of positive balances. Hence, the only demonstrated effect of restricted dietary sodium on the metabolism of potassium was secondary to the metabolism of protein.

The effect of prolonged restriction of sodium on the electrolytes of serum, ascites and urine in a group of patients with cirrhosis was studied (Table III). In the majority of patients, serum sodium, generally low initially, fell slightly immediately after restriction of sodium. However, with continued limitation of sodium, a gradual rise

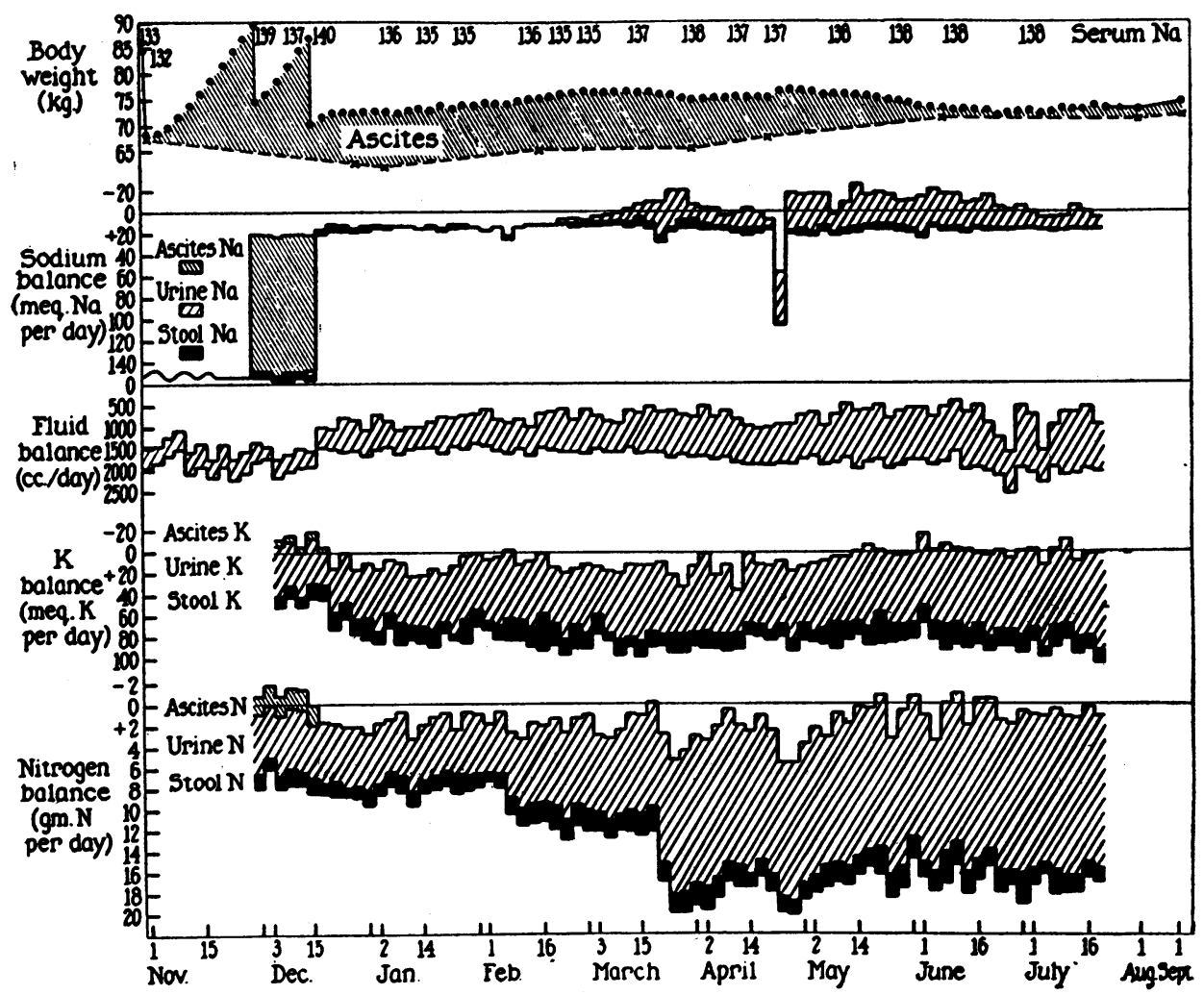

Fig. 2. Immediate Arrest of Formation of Ascites by Restriction of Sodium

Basal weight ( $\mathrm{X}$ on lower weight curve) calculated from determinations of volume of ascites. Balances illustrated in conventional manner : intake charted from baseline downward and output charted from that level upwards. Urine volume is the only fluid output indicated. Positive nitrogen and potassium balances on cessation of accumulation of ascites, reflecting gain in basal weight. Increased excretion of urinary sodium before reabsorption of ascites becomes apparent. 


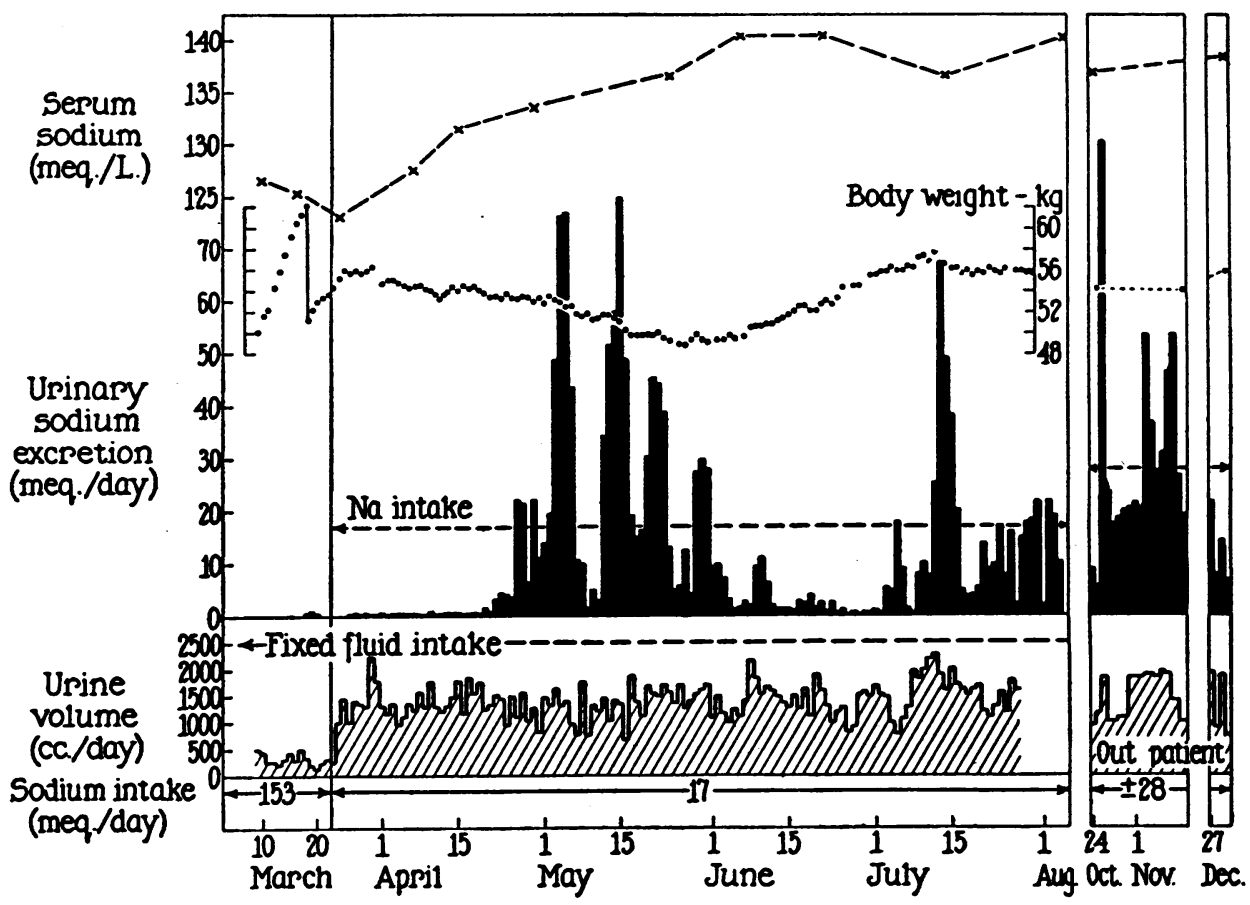

Fig. 3. Rise in Serum Sodium and Fluctuations of Urinary Sodium in Patient Improving While on Restricted INTake of Sodium

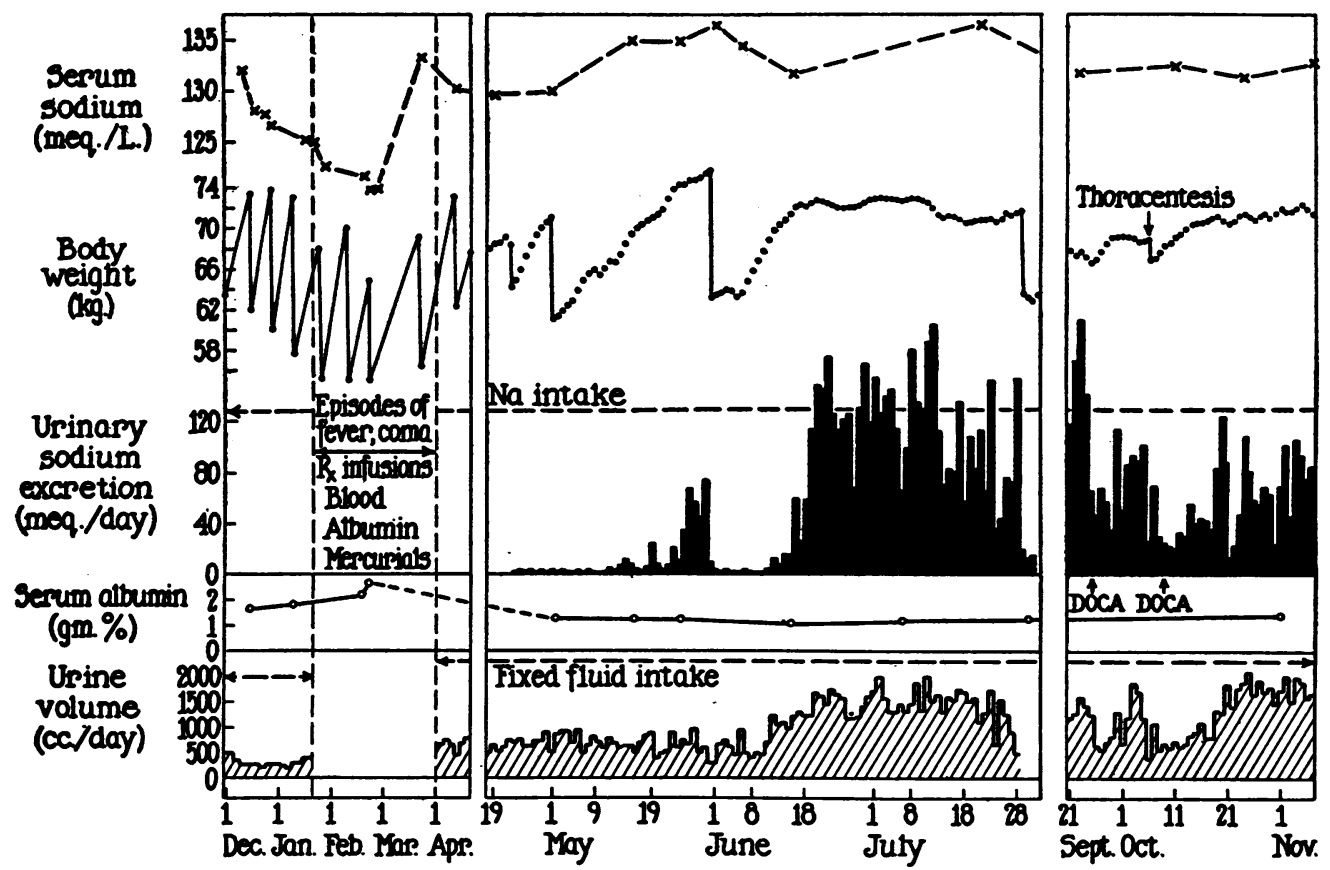

Fig. 4. Course of Patient on Liberal Intake of Sodium

Initial fall in serum sodium with progression of disease. Episode of acute illness followed by elevation of serum sodium. Temporary diminution in excretion of urinary sodium following paracenteses. Variations in urinary sodium unrelated to serum albumin levels. 
TABLE III

ELECTROLYTE STUDIES BEFORE AND ATTER OODIUM RESTRUCTION

\begin{tabular}{|c|c|c|c|c|c|c|c|c|c|c|c|c|c|c|c|c|c|c|}
\hline \multirow{3}{*}{$\mathbf{P t}$} & \multirow{3}{*}{ Day } & \multirow{2}{*}{\multicolumn{3}{|c|}{ Sodium Intak }} & \multicolumn{5}{|c|}{$120-150 \mathrm{meq} / \mathrm{day}$} & \multicolumn{5}{|c|}{ Sodium Intake } & \multicolumn{4}{|c|}{ 15-19 meqiday } \\
\hline & & & & & \multicolumn{3}{|c|}{$\begin{array}{c}\text { Ascitic fluid } \\
\text { meq. } / 1 \text {. }\end{array}$} & \multicolumn{2}{|c|}{$\begin{array}{c}\text { Urine } \\
\text { meq./day }\end{array}$} & \multirow{2}{*}{ Day } & \multicolumn{3}{|c|}{$\begin{array}{l}\text { Serum } \\
\text { meq. } / 1 \text {. }\end{array}$} & \multicolumn{3}{|c|}{$\begin{array}{c}\text { Ascitic fluid } \\
\text { meq. } / 1 \text {. }\end{array}$} & \multicolumn{2}{|c|}{$\begin{array}{l}\text { Urine } \\
\text { meg./day }\end{array}$} \\
\hline & & $\mathrm{Na}$ & $\mathbf{K}$ & Cl & $\mathrm{Na}$ & $\mathbf{K}$ & Cl & $\mathrm{Na}$ & $\mathbf{C l}$ & & Na & $\mathbf{K}$ & Cl & $\mathrm{Na}$ & $\mathbf{K}$ & Cl & $\mathrm{Na}$ & Cl \\
\hline 1 & $\begin{array}{r}1 \\
33 \\
43 \\
46 \\
50\end{array}$ & \begin{tabular}{|l|}
134 \\
139 \\
141 \\
137.5 \\
140
\end{tabular} & $\begin{array}{l}5.2 \\
4.9 \\
4.5\end{array}$ & $\begin{array}{l}110 \\
113\end{array}$ & $\begin{array}{l}140.5 \\
136 \\
140\end{array}$ & $\begin{array}{l}4.5 \\
4.3 \\
4.0\end{array}$ & $\begin{array}{l}120 \\
116 \\
116\end{array}$ & $\begin{array}{l}0.55 \\
0.66 \\
0.68 \\
0.54\end{array}$ & $\begin{array}{l}44 \\
38 \\
39\end{array}$ & $\begin{array}{r}71 \\
92 \\
102 \\
210 \\
224 \\
246\end{array}$ & $\begin{array}{l}134.5 \\
134 \\
137 \\
140 \\
140 \\
139\end{array}$ & $\begin{array}{l}5.3 \\
5.5 \\
45\end{array}$ & $\begin{array}{l}107 \\
107 \\
110\end{array}$ & $\begin{array}{l}133.5 \\
138.5 \\
138 \\
138.5\end{array}$ & $\begin{array}{l}4.3 \\
4.2\end{array}$ & \begin{tabular}{|l|}
114 \\
113 \\
112 \\
\end{tabular} & $\begin{array}{c}0.35 \\
0.32 \\
0.32 \\
37 \\
32 \\
14\end{array}$ & $\begin{array}{l}40 \\
57 \\
62 \\
58 \\
59 \\
43\end{array}$ \\
\hline 2 & $\begin{array}{r}1 \\
7 \\
13\end{array}$ & $\begin{array}{l}126.5 \\
125 \\
123.5\end{array}$ & $\begin{array}{l}7.0 \\
6.8 \\
7.3\end{array}$ & $\begin{array}{l}107 \\
105\end{array}$ & $\begin{array}{l}125 \\
1235\end{array}$ & 6.6 & 110 & $\begin{array}{l}0.25 \\
0.33 \\
0.22\end{array}$ & & $\begin{array}{r}27 \\
35 \\
50 \\
75 \\
126\end{array}$ & $\begin{array}{l}127.5 \\
131.5 \\
133.5 \\
136.5 \\
137\end{array}$ & $\begin{array}{l}4.7 \\
3.8\end{array}$ & $\begin{array}{l}103 \\
111 \\
111\end{array}$ & 137 & 4.8 & $\begin{array}{l}120 \\
117\end{array}$ & $\begin{array}{c}0.50 \\
0.54 \\
6.90 \\
31.10 \\
67\end{array}$ & $\begin{array}{l}0.7 \\
19.1 \\
12.5 \\
24\end{array}$ \\
\hline 3 & $\begin{array}{r}1 \\
35 \\
62 \\
67\end{array}$ & \begin{tabular}{|l|}
129 \\
130.5 \\
128 \\
130
\end{tabular} & $\begin{array}{l}4.9 \\
4.8 \\
4.6\end{array}$ & $\begin{array}{l}101 \\
104 \\
108\end{array}$ & $\begin{array}{l}128 \\
124\end{array}$ & $\begin{array}{l}4.4 \\
4.2\end{array}$ & $\begin{array}{l}109 \\
118\end{array}$ & 0.78 & & $\begin{array}{r}81 \\
139 \\
147 \\
196 \\
219 \\
260 \\
320 \\
\end{array}$ & $\begin{array}{l}131.5 \\
133.5 \\
134 \\
134 \\
136 \\
137.5 \\
144 \\
\end{array}$ & $\begin{array}{l}4.5 \\
4.3\end{array}$ & $\begin{array}{l}108 \\
105 \\
107 \\
100\end{array}$ & $\begin{array}{l}131.5 \\
1325\end{array}$ & $\begin{array}{l}4.1 \\
3.8\end{array}$ & $\begin{array}{l}113 \\
111 \\
\end{array}$ & $\begin{array}{c}0.34 \\
1.04 \\
0.87 \\
5.25 \\
3 \\
30 \\
6\end{array}$ & $\begin{array}{c}0 \\
0 \\
5 \\
10\end{array}$ \\
\hline 4 & $\begin{array}{r}1 \\
97 \\
99 \\
101\end{array}$ & $\begin{array}{l}131.5 \\
131 \\
130 \\
131\end{array}$ & $\begin{array}{l}4.8 \\
5.3 \\
4.8 \\
5.7\end{array}$ & $\begin{array}{l}109 \\
109 \\
108 \\
110\end{array}$ & & & & $\begin{array}{l}0.21 \\
0.17 \\
0.28\end{array}$ & $\begin{array}{l}36.4 \\
45\end{array}$ & $\begin{array}{l}151 \\
157 \\
171 \\
195\end{array}$ & $\begin{array}{l}127 \\
128 \\
128.5 \\
133\end{array}$ & $\begin{array}{l}5.0 \\
4.9 \\
5.0 \\
4.6\end{array}$ & $\begin{array}{l}102 \\
107 \\
108\end{array}$ & $\begin{array}{l}126 \\
127\end{array}$ & $\begin{array}{l}4.7 \\
4.7\end{array}$ & $\begin{array}{l}111 \\
113\end{array}$ & $\begin{array}{l}0.15 \\
0.27 \\
0.27 \\
0.30\end{array}$ & $\begin{array}{l}47 \\
59\end{array}$ \\
\hline 5 & $\begin{array}{r}1 \\
5 \\
18 \\
23\end{array}$ & \begin{tabular}{|l|}
122.5 \\
121.5 \\
123 \\
123
\end{tabular} & $\begin{array}{l}5.8 \\
5.1 \\
5.0\end{array}$ & $\begin{array}{r}96 . \\
98 \\
101\end{array}$ & \begin{tabular}{|l|}
122 \\
121.5 \\
121
\end{tabular} & $\begin{array}{l}5.5 \\
4.9 \\
4.7\end{array}$ & $\begin{array}{l}102 \\
100\end{array}$ & $\begin{array}{l}0.93 \\
0.85 \\
0.82\end{array}$ & $\begin{array}{l}46 \\
10 \\
29\end{array}$ & $\begin{array}{r}58 \\
65 \\
72 \\
115 \\
165\end{array}$ & \begin{tabular}{|l|}
119 \\
122 \\
123 \\
127 \\
131
\end{tabular} & $\begin{array}{l}4.8 \\
5.2 \\
4.5\end{array}$ & $\begin{array}{l}93 \\
95 \\
96\end{array}$ & 122 & 4.1 & 100 & $\begin{array}{l}1.21 \\
0.97 \\
1.40 \\
1.5 \\
6.0\end{array}$ & $\begin{array}{l}1.7 \\
0 \\
1.6\end{array}$ \\
\hline 6 & $\begin{array}{r}1 \\
20 \\
83\end{array}$ & \begin{tabular}{|l|}
131.5 \\
135 \\
131
\end{tabular} & $\begin{array}{l}5.0 \\
5.1 \\
4.3\end{array}$ & $\begin{array}{l}106 \\
104\end{array}$ & $\begin{array}{l}131 \\
133\end{array}$ & $\begin{array}{l}3.8 \\
3.9\end{array}$ & $\begin{array}{l}111 \\
116\end{array}$ & $\begin{array}{l}0.16 \\
0.18 \\
0.15\end{array}$ & $\begin{array}{l}9 \\
1 \\
5\end{array}$ & $\mathbf{P a t}$ & lent & died & & & & & & \\
\hline 7 & $\begin{array}{r}1 \\
13 \\
27 \\
41\end{array}$ & $\begin{array}{l}134 \\
139 \\
140 \\
140\end{array}$ & $\begin{array}{l}4.1 \\
4.6 \\
4.0\end{array}$ & $\begin{array}{l}108 \\
106\end{array}$ & & & & $\begin{array}{l}0.39 \\
0.15 \\
0.37\end{array}$ & \begin{tabular}{|c|}
5.3 \\
12.7 \\
13.9
\end{tabular} & $\begin{array}{r}48 \\
62 \\
84 \\
90 \\
106\end{array}$ & $\begin{array}{l}136.5 \\
132.5 \\
134 \\
138.5 \\
138.5 \\
\end{array}$ & $\begin{array}{l}5.0 \\
4.4 \\
4.6\end{array}$ & 101 & 134 & 4.1 & 108 & $\begin{array}{l}0.52 \\
045 \\
040 \\
0.50 \\
0.60\end{array}$ & $\begin{array}{l}2.6 \\
0 \\
10\end{array}$ \\
\hline
\end{tabular}

* Patients 1 and 4 on Neocurtasal giving high chloride intake.

in serum sodium up to or above the former levels usually occurred. Such a rise in serum sodium was seen in patients who showed the best clinical response. Clinical improvement with obvious loss

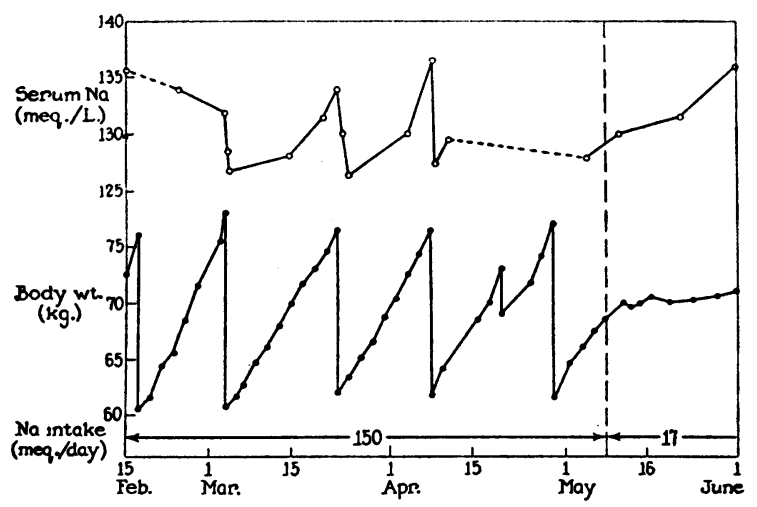

Fig. 5. Fali in Serum Sodium Following Paracenteses in a Patient with Cirrhosis on a Liberal INTAKE OF SODIUM

Rise in serum sodium despite retricted intake of sodium. of ascites follows soon after the increased urinary excretion of sodium.

Chloride was excreted in excess of urinary sodium while the patients were on a liberal intake of salt. Extracellular body fluids maintain a proportion of sodium to chloride of 140 to 105 . Thus, with approximately equal intakes of sodium and chloride, the excess of chloride above that required to balance the maximally retained sodium was excreted. On restriction of sodium, however, dietary chloride likewise was restricted and excretion of chloride fell to minimal levels. Serum potassium, with one exception (Case 2), was normal and did not change after restriction of sodium. The sodium and potassium in ascitic fluid were generally slightly lower than in serum.

\section{Fluctuating excretion of urinary sodium and rising levels of serum sodium during recovery}

The association of clinical improvement with rising levels of serum sodium and increased renal 
excretion of sodium has been indicated above. This is well illustrated in Figure 3 where the rise in serum sodium occurred soon after restriction of sodium. After almost complete absence of sodium in the urine, the renal excretion of sodium increased, fluctuating widely despite a fixed intake of sodium.

Similar changes in urinary and serum sodium may likewise occur during recovery while on a liberal intake of sodium (Figure 4). Following an acute illness, the serum sodium of this patient, initially low, approached normal levels and increased renal excretion of sodium began. The increase in urinary sodium occurred while serum albumin levels remained constant and low.

\section{Effect of paracentesis on levels of serum sodium}

Following paracenteses (Figure 4) there was a prompt fall in urinary sodium. A steady decline in serum sodium is seen in the initial period while the patient was on a moderate intake of salt which necessitated frequent paracenteses. The immediate drop of serum sodium after paracenteses in another patient on a liberal intake of salt and with minimal urinary sodium is shown in Figure 5. A similar response of serum sodium to paracenteses was not found in all patients. However, such a fall in serum sodium following a paracentesis suggests that frequent paracenteses may be a factor in causing low serum sodium in some cases.

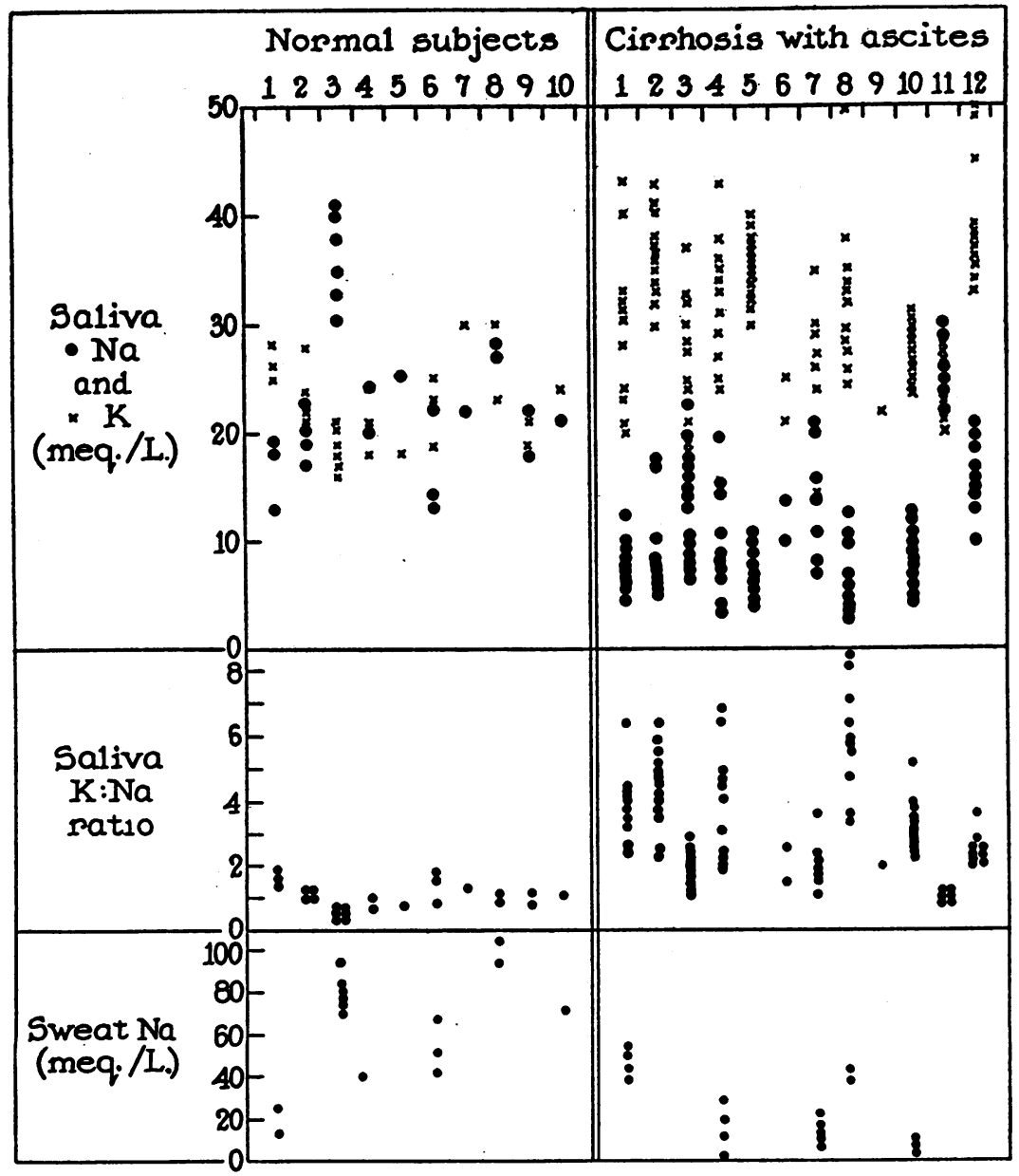

Fig. 6. Depressed Concentrations of Sodium and Elevated Ratios of Potassium to Sodium in Saliva of Patients with Cirrhosis and Maximal. Ascites

Low levels of sodium in sweat of same patients. 


\section{Electrolytes of saliva and sweat}

In the saliva of patients with cirrhosis and ascites the concentration of sodium was usually low and the concentration of potassium high, so that the ratio of potassium to sodium was generally increased (Figure 6). These findings were most abnormal in those patients with maximal accumulation of ascites. In patients without ascites the values were extremely variable. A few determinations on sweat suggested similar reductions of sodium in patients with ascites.

\section{DISCUSSION}

The restriction of ingested sodium to 14 to 20 meq. per day effectively controlled ascites in the majority of patients with cirrhosis. Owing to the minimal excretion of sodium in the urine, dietary sodium should approximate the fecal and dermal loss for successful regulation. Such limitation of sodium was well tolerated. In the presence of normal kidney function, acute symptoms of depletion of sodium occurred only following diuretics or paracenteses. After paracenteses a precipitous fall in serum sodium was found (Figure 5 ), and this has also been reported by Gabuzda, Treager and Davidson (8). It is possible that frequent paracenteses in certain patients contribute toward the maintenance of depressed levels of serum sodium. That other mechanisms are implicated in causing decreased levels of serum sodium is evident from the observations on patients in whom ascites is controlled by restriction of sodium. Certain of these patients not requiring paracenteses maintain low levels of serum sodium for prolonged periods until the eventual rise in serum sodium associated with improvement occurs.

Factors affecting the production and reabsorption of ascites are multiple and include portal "pressure," intra-abdominal pressure, the concentration of serum protein, collateral circulation and the antidiuretic hormone. With progression of the disease, as the rate of accumulation of ascites increases, larger proportions of dietary sodium are utilized in forming ascitic fluid and this is associated with a diminution in the urinary excretion of sodium. The depressed serum sodium suggests that the forces producing ascites are so extreme that ascites is formed out of proportion to available sodium, thereby diluting the sodium in body fluids. On the other hand, a decreasing tendency to form ascites is indicated by a rise in serum sodium and by the increased renal excretion of sodium, two findings which may be present without immediately observable changes in fluid balance. In the course of a profuse diuresis the increased excretion of the water and sodium of the reabsorbed ascites is readily apparent. On the other hand, in the early stages of improvement, when the rate of formation of ascites has only slightly decreased, the increase in the urinary excretion of sodium and water is minimal. However, the rise in urinary sodium, although small, is readily detectable while the changes in fluid balance are not obvious. The reason for this is apparent when one considers, for instance, that 20 cc. of ascites contain 3 meq. of sodium. An increase of $20 \mathrm{cc}$. in the daily urinary output, or a decrease of $20 \mathrm{cc}$. in a large volume of ascitic fluid, is barely detectable. On the other hand, the appearance of an additional 3 meq. of sodium in the daily urine of a patient previously excreting less than 1 meq. per day constitutes a significantly increased output. A pronounced rise in serum sodium occurring during this slow and inapparent reabsorption of ascites is similarly explained.

During the period of maximal production of ascites, sodium is tenaciously retained by the body. Retention of sodium by the kidney may be partially due to alterations in renal hemodynamics. However, the finding of decreased concentrations of sodium also in saliva and sweat of patients with ascites suggests a mechanism of generalized retention of sodium. Conn presents evidence for a relationship between reduced concentrations of sodium in sweat and adrenal cortical hyperactivity (9). Furthermore, he showed a reduction in the concentration of sodium in sweat following administration of desoxycorticosterone acetate and adrenocorticotrophic hormone. That the concentration of sodium in saliva may be under similar adrenal cortical control is suggested by the sustained depression in the concentration of sodium and by the increase in the ratio of potassium to sodium in the saliva of subjects treated with adrenocorticotrophic hormone (10). Therefore, the changes in the electrolytes of urine, saliva and sweat of patients with cirrhosis and maximal accumulation of ascites, correspond to the alterations produced by increased activity of "desoxycorti- 
costerone-like" hormones. Elevated reducing corticoids found in most patients with cirrhosis (10) tend to support this concept. These corticoids have been physiologically related to adrenal "salt and water" hormones, and are the subject of a separate report.

\section{SUM MARY}

1. Most patients with cirrhosis requiring paracenteses at frequent intervals while on a liberal intake of salt excrete less than 1 meq. of sodium daily in the urine. The intake of sodium determined the rate of accumulation of ascites.

2. Extremely low levels of serum sodium appeared to be secondary to maximal formation of ascites. A precipitous fall in serum sodium followed paracenteses in certain patients and appeared to be one of the mechanisms responsible for reduction in serum sodium.

3. A rise in serum sodium and increased urinary sodium indicated decreased production of ascites often long before the associated changes in fluid balance were obvious. The reasons for this are discussed.

4. Low levels of sodium and increased ratios of potassium to sodium were found in saliva of patients with ascites; reduced concentrations of sodium in sweat were also found. These results demonstrate that the retention of sodium by the patient with ascites is a general phenomenon and not solely renal. The possible role of the adrenal gland in the retention of sodium is discussed.

\section{ACKNOWLEDGMENT}

It is a pleasure to acknowledge the technical assistance of Mr. Charles Galati.

\section{BIBLIOGRAPHY}

1. Layne, J. A., and Schemm, F. R., The use of a high fluid intake and a low-sodium acid-ash diet in the management of portal cirrhosis with ascites. Gastroenterology, 1947, 9, 705.

2. Faloon, W. W., Eckhardt, R. D., Cooper, A. M., and Davidson, C. S., The effect of human serum albumin, mercurial diuretics, and a low sodium diet on sodium excretion in patients with cirrhosis of the liver. J. Clin. Invest., 1949, 28, 595.

3. Farnsworth, E. B., and Krakusin, J. S., Electrolyte partition in patients with edema of various origins. J. Lab. \& Clin. Med., 1948, 33, 1534.

4. Eisenmenger, W. J., Ahrens, E. H., Jr., Blondheim, S. H., and Kunkel, H. G., The effect of rigid sodium restriction in patients with cirrhosis of the liver and ascites. J. Lab. \& Clin. Med., 1949, 34, 1029.

5. Gibson, J. G., 2nd, and Evans, W. A., Jr., Clinical studies of the blood volume. I. Clinical application of a method employing the azo dye "Evans Blue" and the spectrophotometer. J. Clin. Invest., 1937, 16, 301.

6. Van Slyke, D. D., and Hiller, A., Application of Sendroy's iodometric chloride titration to protein containing fluids. J. Biol. Chem., 1947, 167, 107.

7. Freyberg, R. H., and Grant, R. L., Loss of minerals through the skin of normal humans when sweating is avoided. J. Clin. Invest., 1937, 16, 729.

8. Gabuzda, G. J., Jr., Treager, H. S., and Davidson, C. S., Hepatic cirrhosis. Factors contributing to the failure to excrete urinary sodium during the accumulation of ascites and edema. J. Clin. Invest., 1950, 29, 814.

9. Conn, J. W., and Louis, L. H., Production of endogenous "salt-active" corticoids as reflected in the concentrations of sodium and chloride of thermal sweat. J. Clin. Endocrinol., 1950, 10, 12.

10. Bongiovanni, A. M., and Eisenmenger, W. J., Role of the adrenal cortex in chronic liver disease. To be published. 